\title{
Career Orientation Of Employees In Islamic Banks: Kingdom of Bahrain
}

\author{
Vijayalaxmi Moovala, PhD
}

Bahrain Institute of Banking and Finance, Kingdom of Bahrain

doi: 10.19044/esj.2016.v12n19p63 URL:http://dx.doi.org/10.19044/esj.2016.v12n19p63

\begin{abstract}
The main aim of the study was to identify the career anchors of employees working in Islamic banks of Bahrain and to examine the similarities or differences, in the career anchor preferences of males and females, managers and non-managers, and among the three generations [baby-boomers, Gen X and Gen Y]. Edgar Schein's eight career anchors formed the basis of this study. The study revealed that there is no significant difference in the career anchor preferences of the male, female, managers and non-managers. The main anchor for majority of these categories was technical/functional competence, for the second majority of respondents it was general managerial competence. The career anchors preference of babyboomers and Gen X, and Gen X and Gen Y was somewhat similar. However there was a variation in the career anchor preferences of baby-boomers and Gen Y. Majority of the baby-boomers and Gen X preferred technical/functional competence as their main anchor, and Gen Y opted for general managerial competence. The preferred anchor for the second majority of baby-boomers was security/stability, for Gen $\mathrm{X}$ general managerial competence and Gen Y pure challenge. The findings of this study would facilitate Islamic banks in Bahrain to develop appropriate career development plans based on their employee preferences. For male, female, managers and non-managers, career plans based on career anchors like technical/functional competence, and general managerial competence need to be made. Whereas for baby-boomers, Gen X and Gen Y relevant career plans based on specific preferences need to be formulated.
\end{abstract}

Keywords: Career anchors, gender, position, generation, correlation

\section{Introduction}

Human capital management, has both a direct and indirect impact on the survival, sustainability and competitiveness of organizations. Organizations, on the global front, are incorporating good practices and latest 
trends in the human capital area to gain a competitive edge in the market. Human resource mechanisms and organizational development interventions are tuned towards employee development. Overall, the focus is on continuous modification of policies and procedures related to employee resourcing, employee talent development, employee compensation and benefits, employee management and most importantly, employee retention. A significant aspect of human capital management is career development and management of employees. For career management to be effective, it is imperative for organizations to understand the varying goals and diverse aspirations of the different categories of employees working with them. The present day corporate sector in the Kingdom of Bahrain comprises employees drawn from different demographic backgrounds having varied career goals and job aspirations. One key factor leading to efficacious human capital management, especially in the key sector of Bahrain which is the Banking sector, is career development and management of its employees.

\section{Banking Sector in Bahrain}

Bahrain's financial sector is well-developed and diversified, consisting of a wide range of conventional and Islamic financial institutions and markets, including retail and wholesale banks, specialized banks, insurance companies, finance companies, investment advisors, money changers, insurance brokers, securities brokers and mutual funds. The sector is therefore well-positioned to offer a wide range of financial products and services, making it the leading financial center in the Gulf region. The financial sector is the largest single employer in Bahrain, with Bahrainis representing over $80 \%$ of the work-force. Overall, the sector contributes $27 \%$ of Bahrain's Gross Domestic Product (GDP), making it one of the key drivers of growth in the country. ${ }^{6}$

Bahrain's banking system consists of both conventional and Islamic banks and is the largest component of the financial system, accounting for over $85 \%$ of total financial assets. The conventional segment includes 23 retail banks, 69 wholesale banks, 2 specialized banks as well as 36 representative offices of overseas banks. The Islamic segment, offering a host of Sharia compliant products and services include 6 retail banks and 18 wholesale banks. The banking sector has played a pivotal role in the emergence of Bahrain as a leading financial center in the region. ${ }^{7}$ In recent years, Bahrain has rapidly become a global leader in Islamic finance, playing host to the largest concentration of Islamic financial institutions in the

\footnotetext{
${ }^{6}$ https://www.cbb.gov.bh/page-p-overview1.htm accessed on 16/08/2015

${ }^{7}$ https://www.cbb.gov.bh/page-p-islamic_finance.htm accessed on 16/08/2015
} 
Middle East. The growth of Islamic banking in particular has been remarkable. ${ }^{8}$

\section{Aim and Scope of the Study}

This study was undertaken in view of the growing importance of Islamic banking in the region and, the significance of career orientation and career development of employees in Islamic banks of Bahrain. The study covered employees of 12 Islamic banks, drawn from both the retail and wholesale sector. The main aim was to study the career orientation of the sample group of employees from these banks. The purpose was to examine the differences or similarities, if any, in the career orientation, between male and female employees, managers and non-managers, and among three generations [namely, baby-boomers, Gen X and Gen Y] of the sample group of employees. The scope of the study did not include the career orientation of senior management of the banks, nor did it extend to a comparative analysis of the career orientation of employees in the Islamic retail and wholesale banks.

\section{Methodology}

For the purpose of this study, both primary and secondary data sources were tapped. Secondary data sources included published articles, journals, books, and websites. Employees of 12 Islamic banks, which were selected on a random basis, constituted the primary data sources for this study. A random sampling method was used to select 200 employees from these Islamic banks. The data collection tool used to elicit data was Edgar Schein's career orientation inventory questionnaire based on his career anchors model. The career orientation inventory questionnaire consist of 40 statements based on work and life experiences. All individuals form an 'anchor' based on these experiences. The eight anchors [listed in Table 1] represent the basic values and desires which motivates employees to take up jobs or make career decisions. ${ }^{9}$ All these statements were rated on a Likerttype scale, with ratings of, 'never true for me -1', 'occasionally true for me - 2', 'commonly true for me - 3', 'often true for me - 4', and 'always true for me -5 '. A section requiring the respondents to fill in their demographic characteristics [gender, position and age category] was added to Edgar Schein's questionnaire which formed the basis for this study.

The questionnaire was sent by mail to some respondents, whereas for others it was administered in person. Of the 200 employees who received the questionnaire, 185 of them responded, giving it a response rate of $93 \%$. The

\footnotetext{
${ }^{8}$ https://www.cbb.gov.bh/page-p-banking.htm accessed on 16/08/2015

${ }^{9}$ [Edgar Schein, 'Career anchors revisited: Implications for career development in the $21^{\text {st }}$ century’, MIT Sloan School of Management.]
} 
responses to the questionnaire were collated and analyzed based on three major categories, namely, i) gender, ii) position [managerial and nonmanagerial], and iii) generations [baby-boomers, Gen X and Gen Y]. The broad age classification of the three generations is given in Table 2. All categories were represented though the respondents, but the percentage representation was not equally distributed among all categories. The data was interpreted and meaningful conclusions were drawn through the use of statistical tools like percentages and correlation.

Table 1: Career anchors

\begin{tabular}{|c|c|}
\hline Acronym & Career anchor \\
\hline TF & Technical/Functional competence \\
\hline GM & General Managerial competence \\
\hline AU & Autonomy/ Independence \\
\hline SE & Security/Stability \\
\hline EC & Entrepreneurial Creativity \\
\hline SV & Service/Dedication to a cause \\
\hline CH & Pure Challenge \\
\hline LS & Lifestyle \\
\hline
\end{tabular}

Table 2: Age classification ${ }^{10}$

\begin{tabular}{|c|c|}
\hline Generation & Age \\
\hline Baby-boomers [BB] & $1946-1965$ \\
\hline Generation X [Gen X] & $1966-1976$ \\
\hline Generation Y [Gen Y] & $1977-1994$ \\
\hline
\end{tabular}

\section{Literature Review}

Career development is not a one-shot training program or careerplanning workshop. Rather, it is an ongoing, organized and formalized effort that recognizes people as a vital organizational resource [Leibowitz, 1987]. In the 1970s, most organizations instituted career development programs to help meet organizational needs, such as preparing employees for anticipated management opening, rather than to meet employees' needs [Morgan, 1977]. Career development is aimed at meeting both employee and employer needs. Career development is viewed as a way of managing the expectations of employees and achieving organizational goals. The assessment phase of career development includes activities ranging from self-assessment to organizationally provided assessment. The goal of assessment, whether, performed by employees themselves or by the organization, is to identify employees' strengths and weaknesses. This kind of clarification helps employees 1) to choose a career that is realistically obtainable and a good fit

\footnotetext{
10 http://www.socialmarketing.org/newsletter/features/generation1.htm accessed on
} $21 / 08 / 2015$ 
and 2) to determine the weaknesses they need to overcome to achieve their career goals [Gomez-Mejia et al., 2010].

Self- assessment usually means doing skills assessment exercises, completing an interests' inventory, and clarifying values (Haskell, 1993). Skills assessment exercises are designed to identify an employees’ skills. An interest inventory is a measure of a person's occupational interests (Anastasi, 1976). Values clarification involves prioritizing personal values. These core values may be considered to be career anchors according to Dr. Edgar Schein, an $\mathrm{MIT}^{11}$ professor who has developed the concept to identify what people most want from a career. He came up with 8 career anchors:

1. Technical/functional competence - to identify with a professional discipline.

2. General management - having a broad, overview, facilitating role, not a specialist.

3. Autonomy/independence - wanting to be self - reliant - useful with today's contracting out.

4. Security/stability - wanting to remain with one employer for life - not so likely any more.

5. Entrepreneurial creativity - a premium wherever innovation drives competitiveness.

6. Service - dedication to worthwhile causes ranging from the environment to poverty.

7. Pure challenge - just solving difficult problems - no pattern necessary.

8. Life style - disinclination to sacrifice life style solely for career advancement.

The basic management implications for each career anchor were summarized as [Gomez-Mejia et al., 2010]:

1. Technical/functional competence - give the employee an opportunity to develop work standards and to mentor others.

2. General management - Give the employee opportunities to lead projects or teams.

3. Autonomy/independence - Ask the employee to take on the role of an internal consultant and tackle a workplace problem.

4. Security/stability - let the employee know that staying in his/her current position is an option.

5. Entrepreneurial creativity - Give this employee new projects and let him/her develop ideas as an internal entrepreneur.

6. Service - offer this employee some responsibility for a company program, such as diversity, or the opportunity to partner with a local charity.

${ }^{11}$ Massachusetts Institute of Technology 
7. Pure challenge - Set stretch goals with the worker and empower him/her to make the decisions needed to get there.

8. Life style - Offer the employee flexibility in his or her work schedule and the opportunity to work from home.

\section{Direction phase}

The direction phase of career development involves determining the type of career that employees want and the steps they must take to realize their career goals. The two major approaches to career direction are individual counseling and various information services (Gomez-Mejia et al., 2010). Individual career counseling refers to one-on-one sessions with the goal of helping employees examine their career aspirations. Skills inventory are company-maintained records with information such as employees' abilities, skills, knowledge, and education (Russell, 1991). Career paths provide valuable information regarding the possible directions and career opportunities in an organization. They point out development needs and options for employees (Erickson, 2008).

\section{Development phase}

The development phase, which involves taking actions to create and increase skills to prepare for future job opportunities, is meant to foster this growth and self-improvement. The most common development programs offered by organizations are mentoring, coaching, job rotation, and tuition assistance (Gomez-Mejia et al., 2010). Mentoring relationships, which can occur at all levels and in all areas of an organization, generally involve advising, role modeling, sharing contacts, and giving general support. Informal mentoring is generally more effective than mentoring done solely as a formal responsibility (Noe, 1988). Organizations offer tuition assistance programs to support their employees' education and development. Tuition and other costs of educational programs (ranging from seminars, workshops, and continuing education programmers to higher education programs) may be entirely covered, or covered contingent upon adequate performance in the program (Gomez-Mejia et al., 2010).

\section{Multiple generations in the workplace}

Today's workplace is more diverse than ever, as most corporations' demographic spans across multiple generations. The babyboom generation continue to play an integral part in today's workplace. Viewed as 'seasoned', thought leaders, or subject matter experts, this generation has a stronghold on experience. They carry critical knowledge and wisdom of decades' worth of industrial, economic, and corporate changes. Gen $\mathrm{X}$ is viewed as independent, resourceful, responsible and 
self-sufficient. They dislike being micro-managed, and embrace a handsoff management philosophy. Their resourcefulness has led them, as a generation, to excel in the workplace by putting in the hours while maintaining a reasonable work-life balance. Gen Y are well-educated and well-groomed with near universal positive reinforcement from authority figures. Differences exist with Gen X and Gen Y on acceptable proportions of work-life balance, quality of work versus quantity of work, and most of all, flexibility. Without question Gen $\mathrm{X}$ and $\mathrm{Y}$ tend to be more flexible in where and how they work, while boomers prefer to have staff in the office, face-to-face, every day. Since today's corporate environment is so multi-generationally expansive, many challenges will inevitably arise, but this type of diversity can also bring unexpected benefits to the blended workforce. ${ }^{12}$

\section{Survey Findings and Data Analysis}

The data from the survey was categorized under three major headings. A gender-wise, position-wise and a generation-wise categorization was made. The percentage of male respondents was $57 \%$ and females $43 \%$. Out of the 185 respondents, 77 [42\%] were in managerial positions [team leaders, branch managers, middle managers, etc.], and 108 [58\%] in nonmanagerial positions. Three generations of employees, that is, baby-boomers, Gen X, and Gen Y, responded to the questionnaire. A generation wise categorization revealed that $32 \%$ of the sample respondents were babyboomers, 50\% were Gen X and 18\% were Gen Y. Each category of gender, positon and generation responded to the questionnaire and identified their preferred anchor. The anchorage of the male and female employees is detailed in the gender-wise analysis, and managerial and non-managerial employees' anchors are discussed under the positon-wise analysis. Anchors of the baby-boomers, Gen X and Gen Y is given under the generation-wise analysis.

\section{Gender-wise analysis}

A gender-wise analysis [see Figure 1] indicated that majority of the male respondents [31\%] opted for the anchor technical/functional competence, followed by the anchor general managerial competence, which was selected by $22 \%$ of them. The preferred anchor for $12 \%$ and $10 \%$ of the males was security/stability and pure challenge respectively. Service/dedication to a cause was selected by $8 \%$ of the male respondents, entrepreneurial creativity by $7 \%$, autonomy by $6 \%$ and lifestyle by $5 \%$ of

\footnotetext{
${ }^{12}$ http://r1consulting.com/baby-boomers-generation-x-and-generation-y-in-the-workplace-a-
} melting-pot-of-expertise/ accessed on 12/09/2015 
them. Technical/functional competence was opted by $27 \%$ of the female respondents and general managerial competence by $18 \%$ of them. Security/stability was the anchor for $14 \%$ of female respondents, and for another $14 \%$ it was pure challenge. About $11 \%$ indicated service/dedication to a cause as their anchor and $8 \%$ chose lifestyle. Only $5 \%$ and $4 \%$ of the female respondents preferred entrepreneurial creativity and autonomy as their anchors respectively.

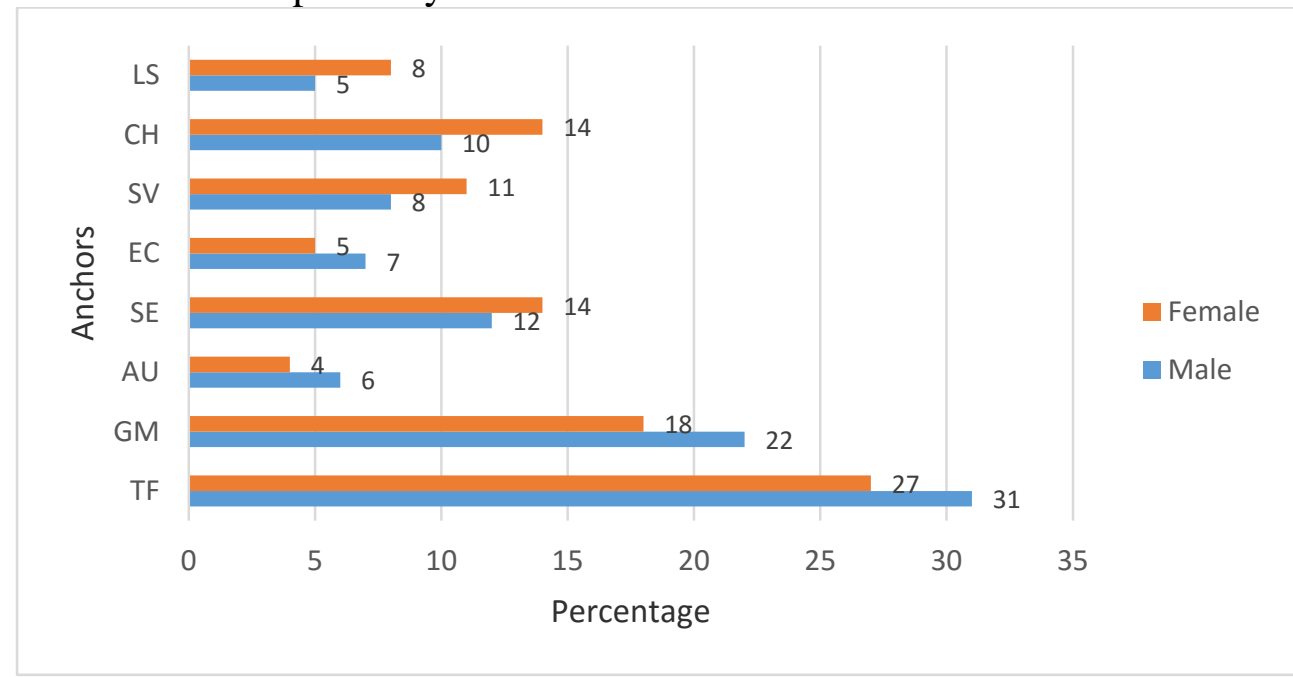

Figure 1: Career orientation: Gender-wise analysis

\section{Position-wise analysis}

A position-wise analysis of the career anchors revealed that majority of the managers [28\%] and non-managers [30\%] indicated technical/ functional competence as their anchor. This was followed by the anchor general managerial competence which was selected by $19 \%$ of the managers and $20 \%$ of the non-managers. Security/ stability as an anchor was preferred by $17 \%$ of the managerial respondents and service/dedication to a cause by $12 \%$ of them. Pure challenge was an anchor for $10 \%$ of the managers, and $5 \%$ of them indicated lifestyle as their anchor with a similar percentage opting for entrepreneurial creativity. Only 3\% of the managerial group opted for autonomy as their anchor. The anchors pure challenge and security/stability were selected by $13 \%$ and $10 \%$ of the non-managerial group respectively. Anchors like lifestyle, entrepreneurial creativity and autonomy were each preferred by $6 \%$ of the non-managerial respondents and service/dedication to a cause by $7 \%$ of them [see Figure 2]. 


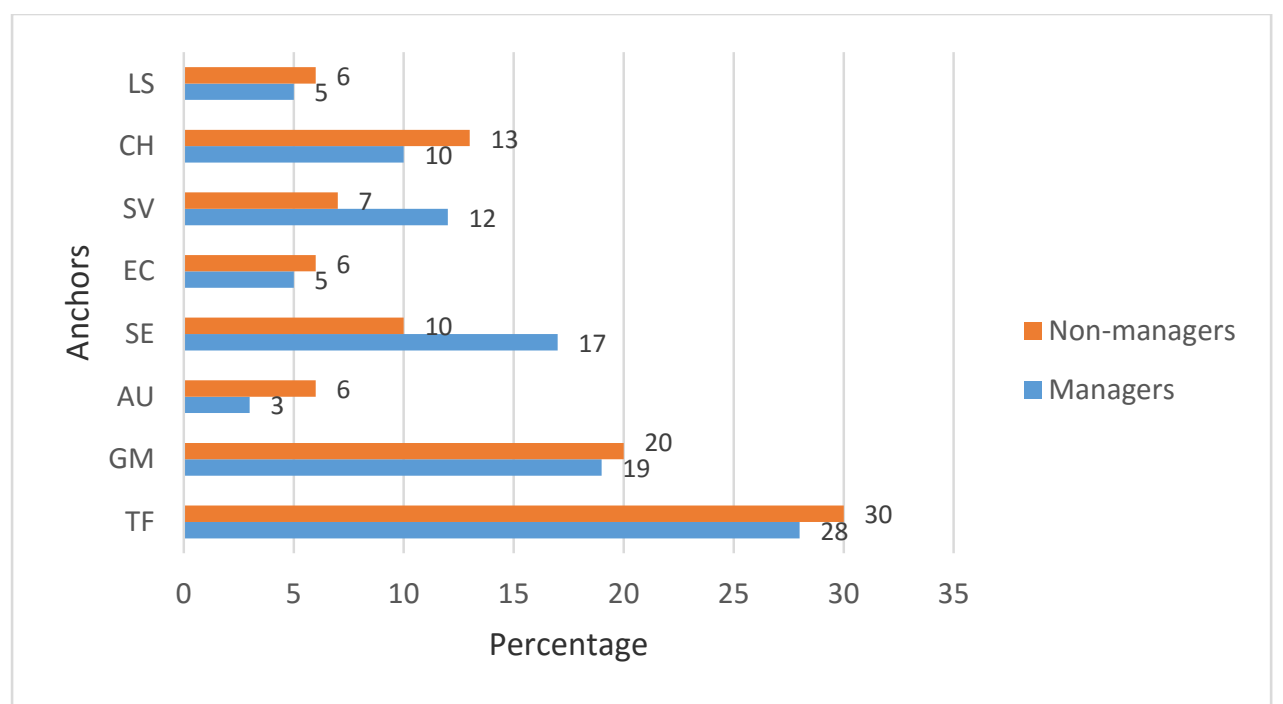

Figure 2: Career orientation: Position-wise analysis

\section{Generation-wise analysis}

A generation-wise analysis [see Figure 3] was done to capture the career anchorage of baby-boomers, Gen X and Gen Y respondents. The baby-boomers' order of preference for career anchors was technical/functional competence [36\%], security/stability [18\%], entrepreneurial creativity [12\%], pure challenge [10\%], general managerial competence [10\%], service /dedication to a cause [8\%], lifestyle [5\%], and autonomy [2\%]. The career anchor selection of respondents belonging to Gen X was technical/functional competence [27\%], general managerial competence [24\%], security /stability [11\%], service/dedication to a cause [11\%], pure challenge [9\%], autonomy [8\%], lifestyle [7\%] and entrepreneurial creativity [4\%]. An interesting trend in Gen Y category was that a majority of them opted for general managerial competence [27\%] and pure challenge [24\%] with $21 \%$ of them selecting technical/functional competence. About $9 \%$ chose security/stability, service/dedication to a cause [6\%], lifestyle [6\%], entrepreneurial creativity [3\%] and autonomy [3\%]. 


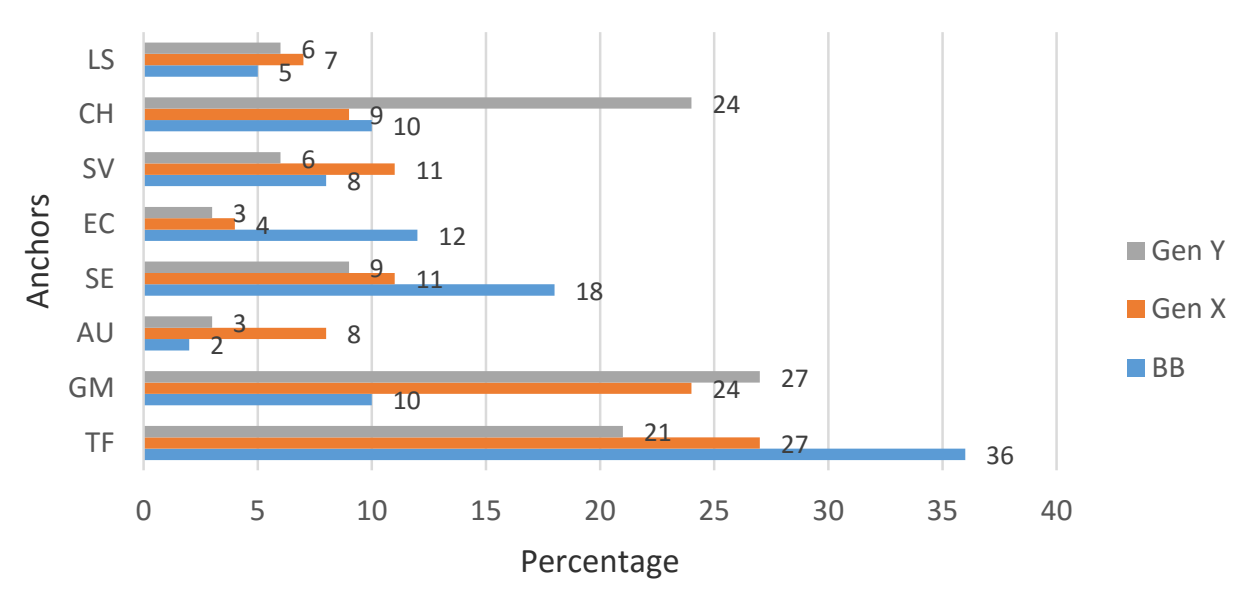

Figure 3: Career orientation: Generation-wise analysis

\section{Statistical interpretation}

This study also examined if there is a difference in the career orientation and preferences between male and female employees, managers and non-managers, and among the three generations of employees [babyboomers, Gen X and Gen Y]. As seen in Table 3, there is an overall positive correlation among the categories that were studied, though the strength of the relationship differed. The strong positive correlation between the genders indicates that there is a high level of similarity in the choice of career anchors between male respondents and female respondents. There is also no major difference in the career anchor preference of managers and nonmanagers as evidenced by the strong positive correlation between them.

Table 3: Statistical interpretation: Correlation

\begin{tabular}{|c|c|}
\hline Category & Correlation coefficient \\
\hline Male/Female & 0.94 \\
\hline Managers/Non-managers & 0.90 \\
\hline Baby-boomers/Gen X & 0.67 \\
\hline Gen X/Gen Y & 0.73 \\
\hline Baby-boomers/Gen Y & 0.41 \\
\hline
\end{tabular}

The career anchor technical/functional competence was selected by majority of the male, female, managerial and non-managerial respondents, followed by the next majority who chose general managerial competence as their main anchor. The third majority of male, female and managerial respondents selected security/stability as their anchor, and an equal majority of the females also chose pure challenge. The third majority of nonmanagers chose pure challenge, which was the preferred anchor for the fourth majority of male respondents. The fourth majority of managers and 
females anchored on service/dedication to a cause, and non-managers on security/stability.

The positive correlation between baby-boomers and Gen X, and with Gen X and Gen Y is not evident between baby-boomers and Gen Y [see Table 3]. This is indicative of the fact that baby boomers and Gen $\mathrm{X}$ being closer in age category have more similar career anchors. The same trend prevails with Gen X and Gen Y. However, the gap of one generation that exists between baby-boomers and Gen Y may have contributed to the career anchors' preference that were not that similar in nature.

A majority of baby-boomers and Gen X selected technical/functional competence as their preferred anchor, whereas it was the choice of the third majority of Gen Y. The second majority of baby-boomers chose security/stability as their anchor, Gen $\mathrm{X}$ chose general managerial competence and Gen Y pure challenge. Entrepreneurial creativity figured as the main anchor for the third majority of baby-boomers, whereas for Gen $\mathrm{Y}$ it was technical/functional competence. An equal third majority of Gen $\mathrm{X}$ respondents chose service/dedication to a cause and security/stability each as their anchors. For the fourth majority of baby-boomers general managerial competence was the main anchor, with an equal majority choosing pure challenge. For Gen X also it was pure challenge whereas for Gen Y it was security/stability.

\section{Conclusion}

The study threw light on the career anchors of employees working in Islamic banks in Bahrain, categorized on the basis of gender, position and generation. There is no significant difference in the overall preferences of career anchors based on the gender and position of the respondents. However, there is a slight shift in the anchors pattern between Gen $\mathrm{X}$ and Gen $\mathrm{Y}$ and a different trend in the anchors preference between baby-boomers and Gen Y.

It can be concluded that career development plans pertaining to promotions or placements in the technical/functional competence area and general managerial competence positions can be applied to the Islamic banks' respondents, irrespective of their gender and position. However, for the three generations [baby-boomers, Gen X and Gen Y] working in the Islamic banks, a differentiated approach to career development and specific policies with regard to career management need to be in place. In the final analysis, career anchors should be given priority and form the foundation for career development in these banks. Examining the career anchor preferences of their employees will give these banks a better insight into their employees' job aspirations and career goals. It would help these banks in 
formulating specific career plans for their employees, instead of establishing general career pathways.

\section{References:}

Anastasi, A. (1976) Psychological testing (4 ${ }^{\text {th }}$ Ed.) NY: Macmillan Deal, J. (2006) Retiring the Generation Gap. San Francisco CA: Jossey-Bass Erikson, T (2008, August 25), Don't trust them like baby boomers, Business week, p 64

Gomez-Mejia, L.R., Balkin, D.B. and Cardy, R.L. (2010) Managing Human Resources, NJ: Prentice Hall

Gravett, L and Robin, T. (2007) Bridging the Generation Gap. NJ: Career Press

Haskell, J.R. (1993) Getting employees to take charge of their careers. Training and development, pp 51-54

https://www.cbb.gov.bh/page-p-banking.htm accessed on 16/08/2015 https://www.cbb.gov.bh/page-p-islamic_finance.htm on $16 / 08 / 2015$

https://www.cbb.gov.bh/page-p-overview1.htm accessed on 16/08/2015 http://r1consulting.com/baby-boomers-generation-x-and-generation-y-in-theworkplace-a-melting-pot-of-expertise/ accessed on 12/09/2015 http://www.socialmarketing.org/newsletter/features/generation1.htm accessed on 21/08/2015

Leibowitz, Z.B. (1987) Developing career development systems: Principles and Practices. Human Resources Planning, 10, pp 195-207

Morgan, D.C. (1977) Career development programs, Personnel, 54, pp 23-27 Noe, R. A. (1988) An investigation of the determinants of successful assigned mentoring relationships. Personnel Psychology, 41, pp 457-479

Russell, J.E. A. (1991) Career development interventions in organizations. Journal of Vocational Behavior, 38, pp 237-287

Schein, E.H. (1978) Career Dynamics: Matching Individual and Organizational Needs. Reading, MA: Addison - Wesley

Schein, E.H. (1993) Career Anchors: Discovering your real values, CA:

Pfeiffer \& Co.

Schein, E.H. (1996) Career Anchors Revisited: Implications for Career Development in the 21st Century. Academy of Management, 10(4): pp 80-88 Schein, E.H. (1995) Career Survival-Strategic job and role planning, CA: Pfeiffer \& Co. 